\title{
WORD MAPPING IN STUDENTS' VOCABULARY MASTERY
}

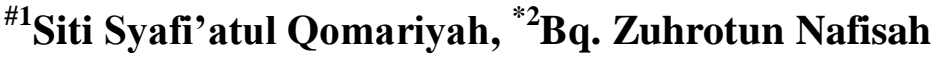

${ }^{\# 1}$ English Lecturer, FBMB, UNDIKMA, Indonesia

${ }^{* 2}$ English Lecturer, FBMB, UNDIKMA, Indonesia

Corresponding Author Email: sitisyafiatulqomariyah@ikipmataram.ac.id

\begin{abstract}
A B S T R A C T S
This research was aimed to find out the effect of word mapping strategy in students' vocabulary mastery. The research was experimental research. The population was the second-grade students of SMP Islam Al-Azhar NW Kayangan which consisted of two classes (60 students). This research used total sampling technique to select the samples VIII.1 class (30 students) as the experimental group and VIII.2 class (30 students) as the control group. This research applied word mapping strategy at experimental group and word wall strategy at control group as treatment. In treatment process, the researchers found that the students were interested when the teacher applied word mapping strategy. The teacher was not only focused on the material but also guided the students to be more interactive in teaching and learning process. To analyze the data, the researchers used descriptive and inferential statistics. The result of data analysis showed that $\mathrm{t}$-test 7.171 with $\mathrm{t}$-table 1.672at the level of significance 0.50 , it was shown that $\mathrm{t}$-test was higher than $\mathrm{t}$-table. On the other words, the hypothesis was accepted.
\end{abstract}

\author{
A R T I CLE IN F O \\ Article History: \\ Received: May, 2020
}

Revised: June, 2020

Published: June, 2020
Keywords:
Word Mapping Strategy,
Vocabulary Mastery,

How to cite: Qomariyah, S., \& Nafisah, B. (2020). Word Mapping in Students' Vocabulary Mastery. Jo-ELT (Journal of English Language Teaching) Fakultas Pendidikan Bahasa \& Seni Prodi Pendidikan Bahasa Inggris IKIP, 7(1), 31-40. doi:https://doi.org/10.33394/jo-elt.v7i1.2736

\section{INTRODUCTION}

The result of observing at SMP Islam Al-Azhar NW Kayangan in the academic year 2018/2019 showed that students felt difficult to spell, pronounce, and memorize the meaning of words. Students were confused when they combined and applied some words in conversation and writing. Dealing with those statements, it could be concluded that the problem faced by students is vocabulary. This research was aimed to find out the effect of Word Mapping Strategy in students' vocabulary mastery. As we know that vocabulary is an important element that must be mastery when they want to be a good speaker and writer. There is no language without vocabulary. According Read (2000) vocabulary is knowledge of knowing the meaning of words they are elements that are combined to make an accurate choice, so it will effectively convey thought and ideas.

Vocabulary is the first step to help someone learn about English. According to Harmer (2007: 35) what a word means is often defined by its relationship to other words. It means that everyone needs to learn what words mean and how they are used. Because of that vocabulary should be mastered and applied in the appropriate context.

Vocabulary is also essential when it comes to a teaching and learning process, especially in English subject. Mastering English Vocabulary is challenging for young students because English vocabularies are something new for them. In the position of acquiring skills, they need to examine a technique that can help them to master English vocabulary. According 
to Singer et al (2003) said that teaching is helping learners to acquire new knowledge or skills. Teaching consists, mainly, of telling, showing, guiding the learner in performance tasks and then measuring the results. Dealing with the statement above, the teachers need to know what kinds of classroom activities so they can help their students to gain new vocabulary. Teaching English vocabulary needs a variety of instructional media that will be able to help the students more attractive in receiving the lesson in the classroom. In other words, the variety of instructional can avoid students to get bored.

Cameron (2001) states that the words of a language split roughly into two groups according to how they are used to construct sentences. The first group, function words are words that must be learned in connection with their use in the sentence. These kinds of words such as noun determiners, auxiliaries, qualifiers, preposition, coordinators, interrogators, and sentence liners. The second group, content words or lexical words are words whose meaning is recorded in dictionaries and often states by means of definitions, synonyms, antonyms, and contextual explanation. These kinds of words are nouns, verbs, adjectives, and adverbs.

Nation (1990) states that to get information about which words will be most useful for learners of English, it can be done by looking at the frequency counts of vocabulary. A vocabulary count is done by making a list of words in a particular text or group of texts and counting how often and where they exist. The following table shows the types of vocabulary, their features, and their implications for teaching and learning.

Knowing a word implies knowing many things about the word: its literal meaning, its various connotations, its literal meaning, its various connotation, its spelling, derivations, collocations, frequency, pronunciation, the kind of syntactic constructions into which it enters, the morphological options it offers and a rich variety of semantic associates such as synonyms, antonyms, homonyms. It means that knowing a word, we have to be sure that we know the word grammatically, syntactically, phonologically, morphologically, and semantically. For example, a student who knows the word "written" will now that it is past tense form and its past participle form. The student would know that "written" is spelled with double "t". The student will also know when and how to use the various auxiliary verb appropriately.

Besides knowing the form of the word, learners also need to be familiar with its grammar. Learners need to now such as irregular forms of verbs or plural nouns, the position of adjectives, etc. Another aspect of teaching vocabulary is word-formation. Students should know how to change a word form and when to use it.

Learning vocabulary is a complex process. In learning vocabulary, students may use the five essential steps as proposed by Hatch et al (2008): (a). Encountering new word (with sources of new words being reading, watching TV, listening to radio, conversation with native speakers, textbooks, word list, dictionary, etc., (b). Creating a mental picture (visual, auditory, or both) pf word form (e.g. relating a new word with L1 words or another FLs with similar sounds, using phonetic script, relating to already acquired English word that sound similarly., (c). Learning the words meaning (e.g. asking the native speaker for the meaning creating a mental image of the meaning, guessing from context)., (d). Creating a strong linkage between word form and meaning in the memory (regardless of the memory strategy used - as long as it is used)., (e). Using words (in example sentences, collocations, various contexts, conversation, etc.

In developing students' vocabulary, the teacher should use a suitable teaching strategy. In this research, the researchers offered a strategy to solve students' problems, especially in vocabulary mastery. There are many kinds of teaching strategies, the researchers are interested to employ word mapping in vocabulary mastery. A definition of word mapping is a graphic rendering of the words' meaning. 
Word mapping is a strategy for representing knowledge in graphs. Knowledge graphs are networks of concepts. Networks consist of nodes (points/vertices) and links (arcs/edges). Nodes represent concepts and links represent the relations between concepts. By the statements, it can be inferred that word mapping strategy is one activity to increase students' vocabulary in English. It is often taught to be one of the most effective ways of integrating language skills in the language classroom. Though the terms word mapping has been interpreted in many different ways by both teachers and textbook writers, both activities offer a flexible yet principled way of tailoring integrated skills to learner needs.

Swanson and Howerton (2007) add using word maps gives students an opportunity to think of a word in a variety of ways. From the statements, the researcher assumes that word mapping activities that are based on graphics often give a useful way to students to have valuable practices, either when they are in the classroom activities or outdoor activities.

Schwarts and Raphael (1985) designed the word mapping in teaching vocabulary, the procedures are as follows: (a) show students an overhead of the vocabulary-mapping organizer. Point out that in order to develop a meaningful definition, the map needs to contain three relationships: "what is it?, "what is it like?", and "what are some examples?"., (b) to model this strategy, the teacher begins by identifying a familiar word that can be easily mapped. (Examples: yogurt, rain forest, shoes)., (c) teacher writes the word on map., (d) ask "What is it?"., (e) ask "what is it like?" Record students' responses on map., (f) ask "what are some examples?" Record students' responses on map., (g) explain to students that the definition now includes properties, categories, and examples.

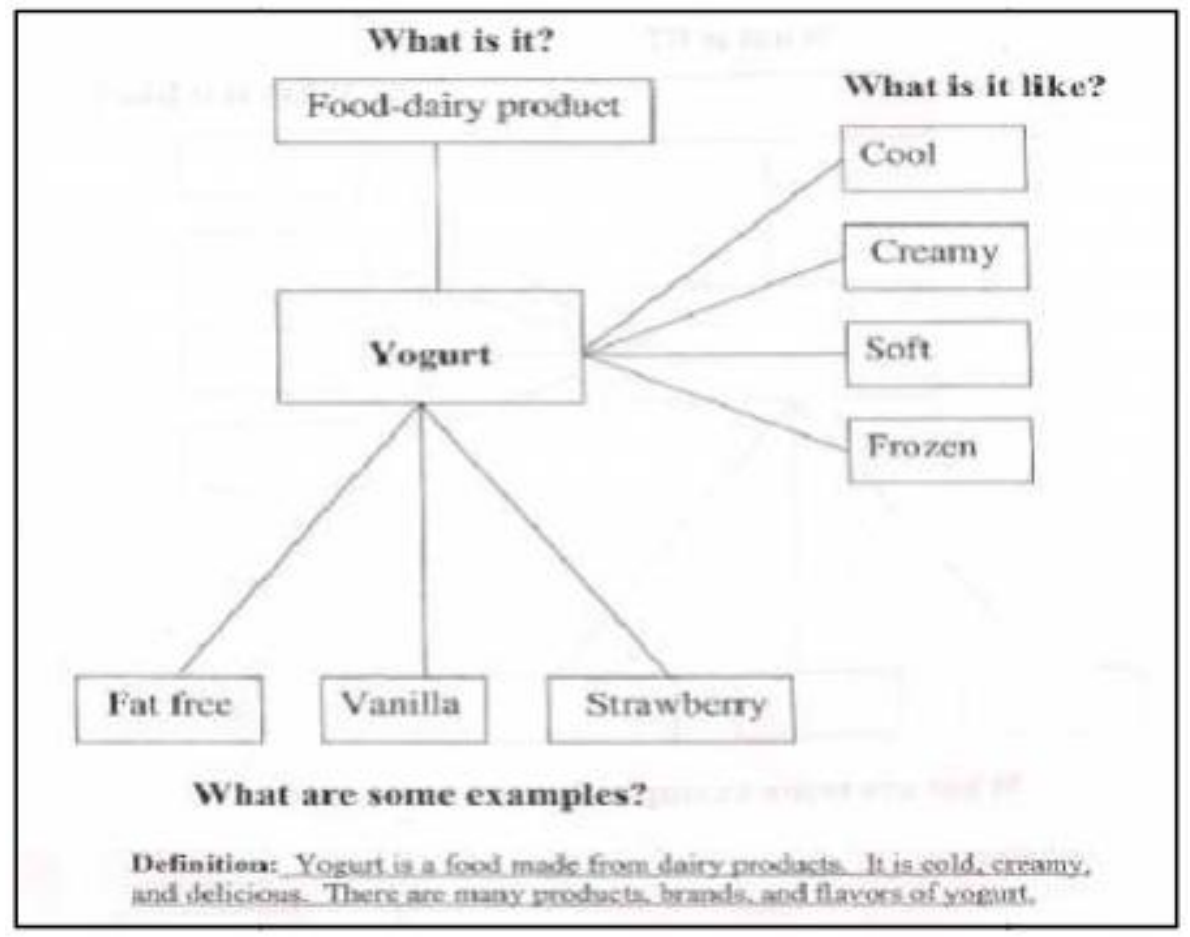

Figure 1. An Illustration of Word Mapping

(Source Revitalizing Vocabulary, North Caroline Teacher Academy)

The researchers propose an alternative way in mastering vocabulary that is by using word mapping technique. Since it is useful for helping students in mastering of word, it can help students think about new terms or concepts in several ways by asking the following questions; what is it?, what is it like?, and what are the examples?. 
Discussing about word mapping, many researchers have conducted for examples, Sari et al, (2018) found that both Vocabulary Self- Collection Strategy (VSS) and Word Mapping Strategy (WMS) are effective to be used in teaching Maritime English Vocabulary to cadets with high and low metacognitive awareness. However, when we compared the effectiveness of VSS and WMS, the findings revealed that VSS was more effective to be used in both high and low metacognitively aware cadets. The statistical analysis showed that there is an interaction between vocabulary teaching strategies, metacognitive awareness, and vocabulary mastery. Coto et al (2017) have proven that semantic word mapping is good to be used in vocabulary teaching. The concept of contextual meaning and learning grammar simplicity covered in students' needs when they are learning vocabulary. However, this research showed a beneficial impact on those who will propose research related to teach vocabulary. Many beliefs claim learning vocabulary is a matter of learning, its meaning, and how to apply it. Teaching vocabulary using semantic word mapping in Junior High School is precise. Widyawati (2016) has found that there is a significant difference in students' vocabulary achievement who were taught by word mapping. Its seen that sig. (p) value (0.010) was less than sig. Level (0.05). it seems the difference between the post-test score of the experimental and control group is positive since the post-test score of the experimental group is higher than in the control group. Based on the questionnaire of students' perception, it was revealed that the students' perception of the implementation of word mapping is positive. It seems that students are not familiar with learning word mapping before they got the treatment by using modified word mapping. But when they already got the treatment, they realize that word mapping can help them in recognizing new vocabulary. Seeing the benefit of word mapping, students think that this technique is very useful for them so that the perception of students is positive.

\section{RESEARCH METHOD \\ Research Design}

The research design that was used in this study is quantitative approach. According to Sugiyono (2017: 7) quantitative approach is as a scientific method because the scientific principles that is concrete or empirical, objective, measurable, rational, and systematic. This method is called the quantitative approach because of the research data in the form of numbers and analysis using statistics. In this study, the researcher applied quasi-experimental with non-equivalent control group design. Sugiyono (2017: 114) states that Quasiexperimental is developing of true experimental design. According to Sugiyono (2017: 116), Non-equivalent control group design is a design that includes in two groups while that experimental group and control group, in this research not chosen by randomly. Experimental group and control group design used by pre-test and post-test. By using this design, the researcher treated different treatments for two groups. The experimental group was treated by using Word Mapping Strategy and control group was treated by using Word Wall Strategy.

\section{Population and Sample}

According to Miller (2005: 53), a population is defined as a collection of all the possible objects, people, or scores of a particular type. The population of this study is the second year students of SMP Islam Al-Azhar NW Kayangan academic year 2018/2019. It consists of two classes (VIII/1, VIII/2), where VIII/1 consists of 30 students, VIII/2 consists of 30 students. The total number of students was 60 students.

Based on the total number of population, the researcher took two classes as the sample of this research; experimental and control class. To determine the sample of this research, the researcher used the total sampling technique, because all of the population are used. 


\section{Instruments}

The research instrument was used as a data collection tool, and instruments commonly used in research (Sugiyono, 2017: 102). The instrument of data collection in this research is vocabulary test in the form of multiple-choice that consists of 25 questions with 4 options (a, $\mathrm{b}, \mathrm{c}$, or d).

\section{Data Analysis}

According to Sugiyono (2011: 137) "Techniques of data collection is one of category concerning the ways in which data is collected, can be done in a various of settings, in various sources and in various ways." It means technique of data analysis is the way to collect any information or the data from the student, to support the researcher to get much information. The techniques of data collection that the researcher used are: (1) Pre-test is the first step of collecting the data. At the first meeting, the researcher gave the same pre-test for both groups (experimental group and control group) as the sample of the research. This pre-test aimed to know the ability of the students' vocabulary mastery before giving the treatment. (2) The post-test is the second step of collecting data in this research. This step was conducted after given the treatment. This test was given to find out the result of the students' vocabulary mastery after treating by using a different strategy.

The technique of data analysis is the way used by the researcher in analyzing the data that has been collected. In this research, the researcher used SPSS 19 in analyzing the data. Descriptive analysis was used to display the important features of the data. The most commonly used measures of central tendency are mean, median, mode, and standard deviation. Meanwhile, inferential statistic is an analysis derived from a sample of data that were used to make inferences about the population from the sample.

In this research, the researchers used a t-test to compute the data which is the interval and derived from two samples. To find out the value of the t-test the researcher used SPSS 19 to find the data. This program helped the researcher to find out the value of the t-test.

To identify whether there is an effect or not Word Mapping Strategy toward students' vocabulary mastery, the research compared the result of the $t$-test and $t$-table. If the $t$-test $\geq t$ table, the alternative hypothesis would be accepted. It means that Word Mapping Strategy have effect toward students in vocabulary mastery. If the t-test $\leq \mathrm{t}$-table, the null hypothesis would be rejected. It means that Word Mapping Strategy have no effect toward students in vocabulary mastery.

\section{RESEARCH FINDINGS AND DISCUSSION Research Findings}

This part was the description of the result of the pre-test before teaching by using Word Mapping Strategy. The result of the data analysis showed the highest score is 60 and the lowest score is 40 , the mean score is 49,60 , the mode score is 48 , the median score is 48,00 , the standard deviation is 5.715. The following data frequency of distribution which was created based on steps of data analysis. 
Table 1

Descriptive Analysis pre-test of Experimental Group

\begin{tabular}{|lr|r|}
\hline $\mathrm{N}$ & Valid & 30 \\
& Missing & 0 \\
Mean & & 49.60 \\
Median & 48.00 \\
Mode & 48 \\
Std. Deviation & 5.715 \\
Range & 20 \\
Minimum & 40 \\
Maximum & 60 \\
\hline
\end{tabular}

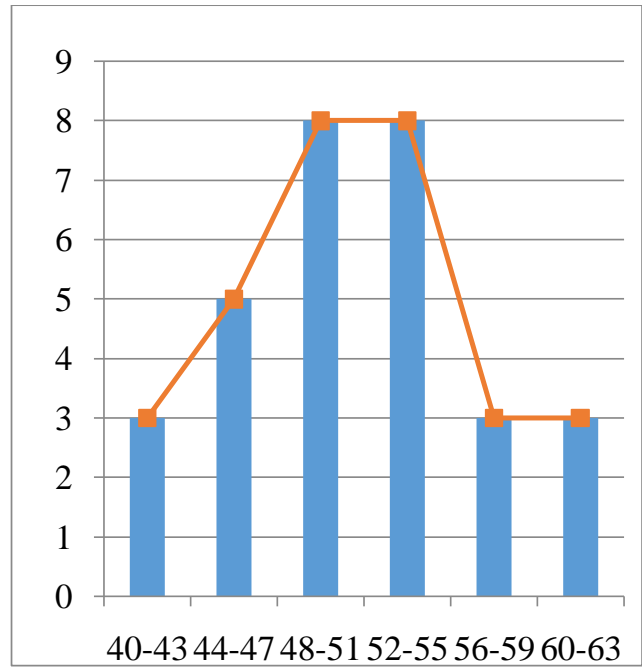

Figure 2. Histogram and Polygon Pre-test Experimental Group

Based on the figure 2, it is shown that the frequency of students who got the score between 40-43 was 3 students. The frequency of students who got the score between 44-47 was 5 students. The frequency of students who got the score between 48-51 was 8 students. The frequency of students who got the score between 52-55 was 8 students. The frequency of students who got the score between 56-59 was 3 students. And the last frequency of students who got the score between 60-63 was 1 student. This section contains the results of research and analysis done with an emphasis on the answer to the problems. The author(s) is recommended to discuss the results according to the findings. In research findings, the author(s) is expected to report the results of procedures in the previous section and to display the data (text, tables, and/or figures) that supports further discussion. Any kind of data should be displayed chronologically as mentioned in the section about methods.

In order to know students' score after the treatment, the researcher gave post-test, then the researcher got the score of the post-test after that the researcher calculated it by using descriptive analysis. Furthermore, the result of the analysis showed that the highest score of the post-test was 92 and the lowest score was 60, the mean score was 72.53 the mode score was 68 , the median score was 72 , the standard deviation was 8.119. The frequency distribution and bar chart of the data were shown in table 2 and figure 3. 
Table 2

Descriptive Analysis Post-test of Experimental Group

Statistics

\begin{tabular}{|c|c|c|}
\hline & $\begin{array}{l}\mathrm{N} \\
\text { Valid }\end{array}$ & 30 \\
\hline & Missing & 0 \\
\hline Mean & & 72.53 \\
\hline Median & & 72.00 \\
\hline Mode & & 68 \\
\hline Std. Deviation & & 8.119 \\
\hline Range & & 32 \\
\hline Minimum & & 60 \\
\hline Maximum & & 92 \\
\hline
\end{tabular}

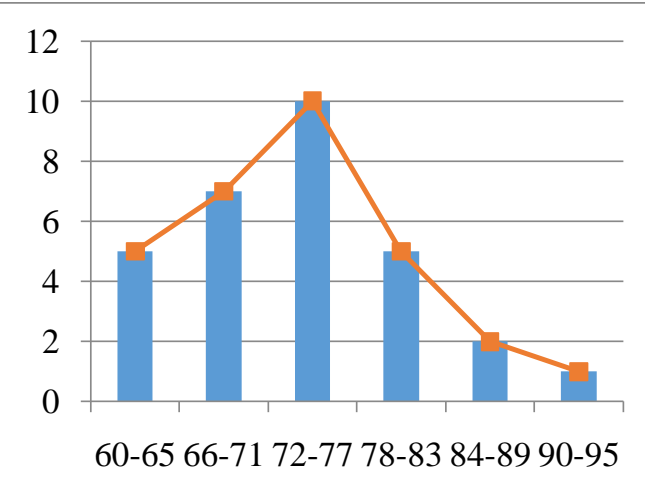

Figure 3. Histogram and Polygon Post-test Experimental Group

Based on the figure 3, it is shown that the frequency of students who got the score between 60-65 was 5 students. The frequency of students who got the score between 66-71 was 7 students. The frequency of students who got the score between 72-77 was 10 students. The frequency of students who got the score between 78-83 was 5 students. The frequency of students who got the score between 84-9 was 2 students. And the last frequency of students who got the score between 90-95 was 1 student.

The data were obtained from students' pre-test and post-test scores from control class. The result of the data analysis showed before giving the treatment using Word Wall Mapping, the highest score was 60 and the lowest score was 40, the mean score was 47,13, the mode score was 40 , the median score was 46,00 , the standard deviation was 7,551. In post-test, the highest score was 78 and the lowest score was 40, the mean score was 56,07 the mode score was 60, the median score was 54,00, the standard deviation was 9,606.

At the end, the result of the testing hypothesis in the t-test formula shows that t-test was 7,171 and the t-table was 1,672 , with significance level 0,05 with the degree of freedom 58 . Therefore, the score of $t$-test was higher than t-table $(7,171>1,672)$, that can be concluded that Null hypothesis $\left(\mathrm{H}_{\mathrm{o}}\right)$, which state: "There is negative effect of Word Mapping Strategy in vocabulary mastery at SMP Islam Al-Azhar NW Kayangan in academic year 2018/2019", clearly was rejected. Therefore, the Alternative Hypothesis $\left(\mathrm{H}_{\mathrm{a}}\right)$, which states: "There is 
positive effect of Word Mapping Strategy in vocabulary mastery at SMP Islam Al-Azhar NW Kayangan in academic year 2018/2019", clearly was accepted.

After computing the result of the data in this research, it was found that Word Mapping Strategy has effect towards students' vocabulary mastery. It showed that the mean score of experimental group was 72.53, and the mean score of control group was 56.07 (72.53 $\geq 56.07)$. Further, the result of calculating the t-test was higher than the t-table. The result of the t-test was 7,171, while the result of the t-table was $1.680(7,171>1,672)$.

Based on the research above, the researcher concluded that Word Mapping Strategy has any significant effect towards students' vocabulary mastery. Therefore, the alternative hypothesis was accepted and the null hypothesis was rejected.

\section{Discussion}

This research aimed at finding the effect of Word Mapping Strategy in students' vocabulary mastery. The result of finding showed that the pre-test and post-test score of both experimental and control group were different. The pre-test and post-test scores of experimental group were higher than the score of pre-test and post-test in control group. It was indicated that this strategy improved vocabulary mastery. It was proven by the ability of students to categorized and arranged words by using word mapping. When students were working together to make a word mapping, their experiences are more meaningful processing of study material. Anderson (2015) stated that more meaningful processing of material can result in better recall. Word mapping is effective to be implemented. By using word mapping, the students can learn how to arrange information or word into a meaningful word map which was easier to be understood and remembered than a plain text. Graves, (2008: 94) defines that the word mapping strategy is one of the most powerful approaches to teaching vocabulary because it engaged students in thinking about word relationships.

Word mapping strategy gave a good contribution to the teacher in teaching vocabulary. Word mapping strategy required a more complex process. Qomariyah and Nafisah (2020) stated that good strategy also give chance for the students to competence in memorizing the vocabularies in the teaching and learning process.

In the implementation of this strategy, there are many phases that is conducted namely (a) show students an overhead of the vocabulary-mapping organizer. In this phase, students could organize the word. (b) to model this strategy, the teacher begins by identifying a familiar word that can be easily mapped. (Examples: Noun, Verb, etc)., according to Anderson (2015) people usually attend to and can remember more easily something that they consider to be meaningful or important., (c) teacher writes the word on map., (d) ask "What is it?"., (e) ask "what is it like?" Record students' responses on the map., the students have a good response when the teacher applied strategy. The students made a map dealing with teacher's instruction., (f) ask "what are some examples?" Record students' responses on map., students could arrange some words and combine the word to be a map, (g) explain to students that the definition now includes properties, categories, and examples. The teacher gave feedback and explain more about the materials. Word Mapping Strategy could give the ability to promote students' deeper understanding of words.

The students should realize that learning English is their requirement. They could not only learn to depend on their teacher. They had a responsibility to learn it by themselves. Especially in learning vocabulary, it was impossible to learn all of the new vocabularies from the teacher. They should learn other sources like the internet, short story, and others. The students also had a responsibility to apply the new vocabulary in their daily life in order to retain their memory of the new vocabulary. Vocabulary is the first step to help someone learn about English. According to Harmer (2007: 35) what a word means is often defined by its relationship to other words. It means that everyone needs to learn what words mean and how 
they are used. Because of that vocabulary should be mastered and applied in the appropriate context.

The teacher was one of the most important factors in teaching English. The teacher was as facilitator and became the key of the success in teaching and learning English. The teacher had to be more creative in design and made a lesson plan. Word mapping strategy could be one of many alternative designs that is able to use in teaching vocabulary. So, the teacher can motivate students to join the activity of learning in the class and they were not bored with the learning process.

The result of this research showed that the word mapping strategy was effective to be applied in teaching vocabulary. In this case, teachers can use word mapping strategy in teaching vocabulary. Since, word mapping strategy gave positive effects in facilitating students to write or organize words.

\section{CONCLUSION}

Based on the analysis, it can be concluded that word mapping strategy has effect in vocabulary mastery. The analysis of pre-test and post-test scores proved that both groups showed improvement after word mapping was applied.

The process of teaching vocabulary through word mapping strategy is good in that the students are mostly satisfied. Before treatments, the students were not familiar with learning word mapping strategy. However, when they already got the treatment, they realize that word mapping strategy could help them in recognizing new words. Seeing the benefit of word mapping, the students think that this strategy is very useful for them so that the perception of the students is positive.

This research focuses on word mapping strategy in vocabulary mastery. The result showed that there is a significant effect of the students' vocabulary mastery between the experimental and control group. Dealing with the result, students' vocabulary mastery in experiment group is better than the students in control group. It means that teaching of word mapping strategy can promote students' vocabulary mastery. This happened due to the fact that word mapping strategy can help students to develop their mastery of vocabulary.

\section{REFERENCES}

Anderson, J. R. (2015). Cognitive Psychology and Its Implication. Worth Publisher: New York.

Anggaraini, D. O., et al. (2019). Improving students' mastery of vocabulary found in reading texts by using word mapping to the first grade. U-JET, 8(2), 1-8.

Cameron, L. (2001). Teaching Language to Young Learners. New York: Cambridge University Press.

Coto, R. Y. (2017). The Use of Semantic Word Mapping in Vocabulary Teaching. Department of Language and Arts Education. Unpublished thesis. Tanjungpura Unversity.

Graves, M. (2008). What Research has to Say about Vocabulary Instruction. New York: International Reading Association.

Harmer, Jeremy. (2007). The Practice of English Language Teaching 4th Edition. New York: Longman.

Hatch, E., \& Farhady, H. (1982). Research Design and Statistics for Applied Linguistics. U.S.A: Newbury House Publishers, Inc.

Karendra, R. (2013). The Implementation of Word Mapping Strategy to Increased Students' Vocabulary Mastery at the First Grade of SMA N 1 Rumbia Lampung Tengah. Bandar Lampung: University of Lampung. 
Nation, I. S. P. (1990). Teaching and Learning Vocabulary. Massachusetts: Heinle \& Heinle Publishers.

Qomariyah, S. S., \& Nafisah, B. Z. (2020) Examining think-talk-write (TTW) strategy in students' vocabulary mastery. JOLLT Journal of Languages and Language Teaching, 8 (1), 72-82. https://doi.org/1033394/jollt.v8il.2240.

Read, John. (2000). Assessing Vocabulary. Cambridge: Cambridge University Press.

Sari, I. L., \& Sutopo D. (2018). The effectiveness of vocabulary self-collection and word mapping strategies for teaching vocabulary to maritime cadets with high and low metacognitive awareness. English Education Journal, 8(1), 35-42.

Schwartz, R. M., \& Raphael, T.E. (1985). Concept of Definition: A Key to Improving Students' Vocabulary. The Reading Teacher, 39(2), 198-205.

Singer, A. J., Murphy, M., \& Hines, S. M. (2003). Teaching to Learn, Learning to Teach. London: Lawrence Erlbaum Associates.

Sugiyono. (2017). Metode Penelitian Kuantitatif Kualitatifdan R\&D. Bandung: Alfabeta.

Swanson, E. A., \& Hawerton, D. (2007). Influence Vocabulary Acquisition for English Language Learner. Intervention in School and Clinic, 42(5), 290-294.

Widyawati. (2016). Investigating the Impact of Word Mapping on the Students' Vocabulary Achievement and the Students' Perception at Junior High School Level. Unpublished thesis. Department of Language and Arts Education: Lampung University. 